\title{
UMA BATALHA DE PAPÉIS: A SUSPENSÃO E AS CRÍTICAS À INQUISIÇÃO PORTUGUESA (1670-1674)
}

\author{
YLLAN DE MatToS \\ Universidade Estadual Paulista (Brasil)
}

Fecha de recepción: enero 2015

Fecha de aceptación: mayo 2015

\author{
Com cristão zelo e piedade \\ quer a santa casa que \\ a vozes de viva a fé \\ não seja ouvida a verdade. \\ Vive absoluta e sem lei \\ sendo de virtude a capa: \\ quando o rei manda, é do papa, \\ e quando o papa, é do rei.
}

Quadras fixadas na esquina da Inquisição (1679) Antônio Vieira. Cartas, Tomo III. p. 281.

\section{A CAUSA DE VIEIRA E OS PREPARATIVOS DO PERDÃO-GERAL}

O padre Antônio Vieira seguiu para Roma no ano de $1669^{1}$. Sua intenção oculta era a revisão de seu processo inquisitorial. Contudo, nos primeiros anos - como

\footnotetext{
1. O jesuíta Antônio Vieira (1608-1697) foi uma das pessoas mais importantes no horizonte histórico-literário do século XVII luso-brasileiro, participando desde o alto jogo politico, em Portugal, às estratégias de conversão jesuítica e definição da jurisdição sobre a mão de obra indígena no norte do Brasil. Vieira foi processado pela Inquisição de Coimbra em 1663 (data do primeiro interrogatório), preso dois anos depois e sentenciado em 1667. À época, havia sido expulso do Maranhão e o rei dom Afonso VI, de facção política rival ao jesuíta, assumia o trono. Sobre o jesuíta, ver: AzEvedo, João Lúcio de: História de Antônio Vieira. Prefácio de Pedro Puntoni. São Paulo: Alameda, 2008. VAINFAS, Ronaldo: Antônio Vieira: jesuíta do rei. Coleção perfis brasileiros. São Paulo: Companhia das Letras, 2011.
} 
destacam seus biógrafos e demonstra sua correspondência -, penava de todo jeito, chegando a afirmar a Rodrigo de Menezes: «os italianos não entendem o que digo e os castelhanos querem entender mais do que digo $\rangle^{2}$. Entretanto, o jesuíta pouco a pouco foi galgando espaço na Cidade Eterna e ganhando destaque na corte romana, já no pontificado de Clemente X (1670-1676) ${ }^{3}$.

As incumbências oficiais de Vieira seriam negociar junto ao papa, por rogo do provincial do Brasil, a canonização de alguns mártires jesuítas devorados pelos índios tupiniquim ${ }^{4}$. O caminho escolhido para chegar a Roma não agradou o regente dom Pedro, que vetou sua passagem pela Inglaterra (onde visitaria a rainha, dona Catarina de Bragança) e França (encontrando-se com o enviado Duarte Ribeiro de Macedo), como quisera o padre. Pode ser que alguma «maquinação» tramasse com os «hebreus», que decerto faziam «grandes diligências por alcançar o perdão-geral» - como se desconfiava na Corte, conta-nos frei Alexandre da Paixão, em um dos melhores relatos dessa época 5 . Talvez, a passagem pela Inglaterra se devesse à trama que lá ocorria. Estavam o residente Gaspar de Abreu Freitas, o provincial do Malabar, padre Baltazar da Costa, e alguns cristãos-novos, entre eles o riquíssimo banqueiro Duarte da Silva - outrora financiador da Restauração dos Braganças (1640), réu do Santo Ofício e amigo de Vieira. Com razão discordou Ronaldo Vainfas ${ }^{6}$, pois não havia até a altura de 1669 qualquer indício de perdão geral ${ }^{7}$. De todo modo, seguiu viagem pelo Mediterrâneo.

Em outra carta a Rodrigo de Menezes, Vieira confessou seu propósito:

não quero ter pleito algum com os inquisidores de Portugal, que foram meros executores das censuras, e só quero e devo ter com os ministros de Roma que as censuraram, e pedir ao Papa que, pois eu não fui ouvido, me ouça e, depois de cuidar a razão do que eu disse, mande julgar de novo o que for justiça. Assim que, o meu pleito todo é em Roma

2. VIEIRA, Antônio: Cartas. Organização e notas de João Lúcio de Azevedo. São Paulo: Globo, 2009. Tomo II. p. 242. Carta de Antônio Vieira a dom Rodrigo de Menezes (20 de junho de 1671). Este trecho também está citado em VaInfas, Ronaldo, Op. cit. p. 244; e Azevedo, João Lúcio de, op. cit. Tomo II. p. 138.

3. Segundo sua formulação, já bastante castigado pela idade «o papa [apenas] vive, o cardeal [Altieri] reina». Idem. p. 241. Carta de Antônio Vieira ao marquês de Gouveia (6 de junho de 1671)

4. VAINFAS, Ronaldo, op. cit. p. 242.

5. PAIXÃo, Frei Alexandre da: Monstruosidades do tempo e da fortuna: diário de fatos mais interessantes que sucederam no reino de 1662 a 1682. Edição de Graça Barreto. Lisboa, Tavares Cardoso \& Irmão, s/d. p. 109.

6. VaInfas, Ronaldo: Antônio Vieira, op. cit. p. 243.

7. Segundo afirmou dona Catarina de Bragança, rainha da Inglaterra, «só porque os inquisidores não imaginassem que sua alteza, por este rodeio, consentia no fim da jornada, me não concedeu que passasse uma vez, por amor de mim, aquele mesmo canal de Inglaterra, em que sete vezes me vi perdido pela conservação da sai coroa». Poderiam os inquisidores terem desconfiado de algum outro motivo para vetarem-lhe a passagem pela Inglaterra? VIEIRA, Antônio: Cartas, op. cit. Tomo II. p. 204. Carta de Antônio Vieira à dona Catarina de Bragança, rainha da Inglaterra (21 de dezembro de 1669). 
com os ministros romanos, não entrando para mal nem para bem nesta causa os ministros de Portugal ${ }^{8}$.

Vieira não parecia ter muito em conta os inquisidores portugueses. Quando processado, só recuou em sua defesa no momento em que a ressurreição de dom João parecia-lhe impossível, passado o derradeiro ano de 1666, e quando foram apresentados os pareceres dos qualificadores romanos e a desaprovação papal ${ }^{9}$. Todavia, os inquisidores coimbrenses já tinham antevisto essa situação antes mesmo de proferirem a sentença, a julgar pelo que aconselharam na conclusão dos autos:

que o réu não possa sair deste reino sem licença da Inquisição, pois se pode, de alguma maneira, recear que vendo-se fora dele, com a lembrança [e sentimento] de haver sido preso e rigorosamente examinado e arguido de suspeita de judaísmo e outros erros heréticos pelas ditas proposições, negando-se-lhe o procurador e livros que pedia, poderá detrair do procedimento e estilos do Santo Ofício e infamá-los livremente, parecendo-lhe com isso recupera e saneia a opinião perdida ${ }^{10}$.

O jesuíta não era de molde a recuar diante de uma peleja, não podendo os inquisidores estarem mais certos na sua previsão. Roma era o lugar perfeito e os acontecimentos em Portugal vinham bem a calhar. O clima tenso, após o sacrilégio em Odivelas $(1671)^{11}$, mostrou-se insuportável para os cristãos-novos. A Coroa e as cortes propunham as mais deletérias soluções, como a interdição de cargos, a proibição dos casamentos mistos e o desterro aos condenados pelo Santo Ofício; a Inquisição, embora contrária à última proposta, reiterava também algumas proibições, entre elas vetar aos cristãos-novos condenados receber rendas, hábitos ou comendas da Coroa, andar de coche ou a cavalo, usar sedas ou joias; o povo, por sua vez, depredava propriedades e agredia os cristãos-novos nas ruas. Foi, no entanto, a prisão de uma série de ricos contratadores que causou pânico e rebuliço entre os homens da nação: a família dos Mogadouros, dos Pestanas, dos Chaves, além de

8. VieIra, Antônio: Cartas, Op. cit. Tomo II. p. 199. Carta de Antônio Vieira a dom Rodrigo de Menezes (3 de dezembro de 1669). Em carta à dona Catarina de Bragança, Vieira afirmava: «determino pleitear de novo a minha causa e buscar em Roma a justiça que não achei em Portugal». Idem. p. 204. Carta de Antônio Vieira à dona Catarina de Bragança, rainha da Inglaterra (21 de dezembro de 1669).

9. ACDF [Archivio della Congregazione per la Dottrina della Fede], Stanza Storica, BB 5-c.

10. Parecer dos inquisidores de Coimbra para o Conselho Geral, assinado por, entre tantos, Jerônimo Soares - futuro adversário de Vieira em Roma. Os autos do processo de Vieira na Inquisição. 1660-1668. Edição, transcrição, glossário e notas de Adma Muhana. São Paulo: Edusp, 2008. p. 406. Ver, igualmente, Calafate, Pedro (Coord.); Borges, Paulo (Org.): Padre António Vieira: defesa perante a Inquisição. Lisboa: Círculo dos Leitores, 2014. Tomo III, Volume II.

11. A igreja de Odivelas, em maio de 1671, havia sido roubada. Algumas peças dos santos e hóstias foram retiradas da igreja e tão logo foram responsabilizados os conversos pelo nefando sacrilégio. Orações, procissões, versos antijudaicos e uma inaudita violência contra os cristãos-novos foi sentida por todo o reino. O climax anti-judaico chegou ao seu extremo, mesmo após a prosão do verdadeiro criminoso: Antônio Ferreira, um rústico cristão-velho. Sobre este caso, ver também: MARTINS, Jorge: O senhor roubado: a Inquisição e a questão judaica. Lisboa: Europress, 2002. 
outras nove famílias ${ }^{12}$. As reclusões aconteceram entre julho e agosto de 1672 e deram azo para que alguns cristãos-novos, com o importante apoio jesuítico, começassem a acertar a proposta de um novo perdão-geral, no mês setembro. Um mês antes, o embaixador espanhol deu conta a Madri que os inquisidores portugueses causaram perturbação e espanto, pois haviam prendido «muita gente e, entre eles, os homens de maior cabedal deste comércio» ${ }^{13}$.

O provincial dos jesuítas em Malabar, Baltazar da Costa, acordou os pontos pelos quais seria feita a proposta, contando com o «diplomata» português, Gaspar de Abreu de Freitas, e, certamente, o banqueiro Duarte da Silva. A prisão dos comerciantes de maior cabedal deu o incentivo final à proposta. $\mathrm{O}$ papel fora entregue ao confessor de dom Pedro, o jesuíta Manuel Fernandes, encarregado de fazer a vez com o regente. Tudo estava acertado, sobretudo o importante apoio da Universidade de Évora para a justificativa teológica ao irmão do rei. A proposta consistia que «a gente de nação desejando somente que suas causas sejam examinadas em ordem a todo o castigo e com toda a verdade católica», sem duvidar dos «inconvenientes que nos procedimentos deles pode haver, não por falta do Santo Tribunal da Inquisição que reconhecem por muito inteiro na justiça e benigno na misericórdia», mas na «confusão» e «falta de verdade que há da parte de alguma gente da nação em suas acusações originada [sic] de alguns respeitos e intentos menos» justos. Com a clareza do cristianismo, «pedem se lhe conceda por esta vez somente perdão-geral para todos como se até o tempo em que se lhe conceder não houvessem delinquido e se veem soltos todos os presos livremente», permitindo «serem julgados no Santo Tribunal da Inquisição assim como o santo padre os julga em Roma» ${ }^{14}$. Essas linhas traziam a baila os Memoriais do período filipino ${ }^{15}$. Pautavam seu discurso na possibilidade de haver culpados, mas também de pleitos injustos e desiguais quanto ao modo de proceder observado em Roma, solicitando, por fim, a licença para ir a Sé Apostólica buscar o perdão-geral, em troca de - já em março de 1673 - muitos investimentos nas índias portuguesas ${ }^{16}$.

12. Azevedo, João Lúcio de: História dos cristãos-novos portugueses. Lisboa: Clássica, 1989. p. 294. Ver também, embora com diversas imprecisões: Andrade, António Júlio de; Guimarães, Maria Fernanda: $A$ tormenta dos Mogadouro na Inquisição de Lisboa. Lisboa: Veja, 2009.

13. AGS [Archivo General de Simancas], Secretaría de Estado - Negociación de Portugal. Legajo 2623. Carta de Baltasar de Eraso y Toledo, conde de Humanes, para a regente Mariana de Áustria (4 de agosto de 1672). Original em espanhol. Tradução nossa.

14. DGA/TT [Divisão Geral de Arquivos/Torre do Tombo], Conselho Geral. Mç. 7, doc. 2535. BA [Biblioteca da Ajuda], 49-IV-26, n. ${ }^{\circ} 10$.

15. Ver o primeiro capítulo de MatTos, Yllan de: A Inquisição contestada: críticos e críticas ao Santo Ofício português (1605-1681). Rio de Janeiro: Mauad-x, 2014.

16. Idem. Uma cópia resumida foi apensada a um pequeno memorial dado aos cardeais da Congregação romana, encontrada em ACDF-Roma, Stanza Storica, BB 5-d. Vera relatione di quello ch'è passato nel negotio della gente della natione sopra il perdon generale. Original em italiano, sem paginação. A cópia em português desse memorial, de provável autoria do padre Manuel Fernandes, encontra-se em DGA/TT, Armário jesuítico, maço 29, documento 23. Narração verdadeira do que se tem passado com o negócio da gente da nação. Segundo afirma Ana Maria de Faria, a proposta teria influência do papel 
A questão fora remetida ao Conselho Geral do Santo Ofício que, como era de se esperar, se lançou por inteiro contra ela. Porém, a generosa proposta dos cristãos-novos fora tão logo aceita por dom Pedro que apoiou o intento, escrevendo ao papa para que examinasse «o requerimento do perdão-geral e reforma dos estilos da Inquisição», pretendido pelos cristãos-novos, deferindo com toda a justiça que se observa em semelhantes $\operatorname{casos}^{17}$. Essa carta do regente havia sido ancorada em pareceres de doutores, lentes e ministros da Universidade de Évora que eram unânimes em afirmar que não se podia impedir a solicitação em Roma e que não havia problema algum em aceitar os donativos dos homens de negócio ${ }^{18}$. Os jesuítas, assim, faziam voz a uma questão de quase trinta anos: a licitude do recurso ao santo padre ${ }^{19}$.

Os argumentos apontavam quase em uníssono que se tratava de assunto espiritual e sobre leis eclesiásticas, não cabendo a proibição do recurso, mas, quem o fizesse, experimentaria as censuras descritas na bula da ceia. Ao que parece, Vieira também proferiu opinião, criticando as «distinções de sangue [...] que o inimigo comum introduziu em Portugal para a ruína da união evangélica», além de afirmar:

causam et causam entre a causa e pretensão dos cristãos-novos e dos inquisidores, querendo os uns serem julgados por leis feitas conforme o Direito e os sagrados cânones para não parecerem inocentes e querendo os outros julgados por estilos e praxe que não sabemos seja aprovada pela Sé Apostólica ${ }^{20}$.

cunhado por Duarte da Silva, em 1663, no qual apresentava a criação de uma Companhia de Comércio e a promoção de um perdão-geral e da reforma dos estilos da Inquisição. FARIA, Ana Maria Homem Leal de: 'Uma teima: do confronto de poderes ao malogro da reforma do Tribunal do Santo Ofício. A suspensão da Inquisição portuguesa (1674-1681)' In: BARreto, Luís Filipe; Mourão, José Augusto; Assunção, Paulo de; Gomes, Cristina da Costa \& Franco, José Eduardo (coords.): Inquisição portuguesa: tempo, razão e circunstância. Lisboa/São Paulo: Prefácio, 2007. p. 87-88. Essa proposta encontra-se em BNP [Biblioteca Nacional de Portugal], Reservados, Códice 868. fls. 441-442. Giuseppe Marcocci e José Pedro Paiva também afirmam que o plano fora desenhado em Londres, contando com «o apoio de Duarte da Silva e do residente português na capital britânica, Gaspar de Abreu de Freitas». MARCOCCI, Giuseppe; PAIVA, José Pedro: História da Inquisição portuguesa (1536-1821). Lisboa: Esfera dos Livros, 2013. p. 203.

17. DGA/TT-Lisboa, Armário Jesuítico. Maço 29, documento 45.

18. A primeira e segunda lista dos que votaram a favor do recurso dos cristãos-novos em Roma está em DGA/TT-Lisboa, Armário Jesuítico. Maço 29, documento 35. Já os pareceres de Francisco de Almada, Francisco de Abreu Godinho e de outros doutores, lentes e ministros que votaram que o rei podia promover em Roma o requerimento dos cristãos-novos, que não era lícito impedi-los e que podia aceitar o donativo que lhe ofereciam, encontra-se em DGA/TT-Lisboa, Armário Jesuítico. Maço 29, documento 38. Neste maço (29), há diversos pareceres e opiniões sobre o caso.

19. A questão se relaciona com um conflito de privilégios entre os inquisidores e a Universidade, ambos de Évora, no ano de 1641. Na época, o rei decidiu em benefício dos inquisidores. Porém, os jesuítas escreveram ao papa e conseguiram que o santo padre lhes apoiasse a causa, causando certo constrangimento à Coroa que, além de ter suas determinações desobedecidas, estava com as relações rompidas com o papado que não reconhecia a legitimidade do novo reinado. Ver o segundo capítulo de: MATTOS, Yllan de, op. cit.

20. DGA/TT-Lisboa, Armário Jesuítico. Maço 29, documento 36. 
A questão provocou uma verdadeira batalha de pareceres e opiniões. Eram textos manuscritos bem dinâmicos que não passavam por nenhum tipo de censura (sendo alguns deles produzidos pelas próprias instituições censoras), pois a agilidade e a circulação definiam muitas vezes a hegemonia na cena política. Por isso, mesmo sem qualquer solicitação, as facções emitiam opiniões que expressavam tanto sua crença quanto a tentativa de dominar a arena de batalha. De um lado, estavam os jesuítas, alguns secretários e pouquíssimos bispos defendendo a causa cristã-nova e ávidos por torpedear o Santo Ofício. Do outro, os inquisidores e a maioria esmagadora dos prelados, além do Estado do Povo e de alguns setores tradicionais. Isso não significa dizer que todas as pessoas apoiaram como bloco cada instituição. Existiam algumas nuanças no jogo que tornavam essa batalha de papéi ${ }^{21}$ imprevisível aos olhos de seus integrantes. Embora os jesuítas tenham saído na frente, os inquisidores não tardaram a mobilizar a facção que os apoiava.

\section{O PLEITO EM ROMA E AS PERTURBAÇÕES EM PORTUGAL}

Os cristãos-novos, já nesse momento autorizados pelo regente, agilizavam seu pleito em Roma, fazendo seus procuradores o marquês Francisco Nunes Sanches, dom Francisco da Silva, Francisco Peres Vergueiro e Baltazar Gomes Homem, em 24 de julho de $1673^{22}$. Porém, mais à frente (20 de outubro), em nome de «todos os homens cristãos católicos da nação hebreia» de Portugal, Antônio Rodrigues Marques, dom José de Castro e Manuel da Gama e Pádua - os mesmos que assinaram a procuração acima - fizeram o abade Francisco de Azevedo, residente na corte de Roma, procurador de sua causa, com o apoio do príncipe regente - como chegaram a afirmar nessa altura $^{23}$.

No reino, o clima era tão instável que os partidários do retorno de dom Afonso VI se agitavam ${ }^{24}$. Segundo o autor de Monstruosidades do tempo e da fortuna, fora fixado na porta da capela real, no mês de julho, o seguinte aviso:

21. A inspiração para esta expressão veio do conceito Monarquía de Papeles, de Fernando Bouza. Corre o manuscrito: uma historia cultural del Siglo de Oro. Madri: Marcial Pons, 2001. p. 162. Ver também do mesmo autor: 'Felipe IV sin Olivares: la restauración de la monarquía y España en avisos' In: Antonio Eiras Roel (dir.). Actas de las Juntas del reino de Galicia (1648-1654). Santiago de Compostela: Dirección Xeral de Patrimonio Cultural de la Xunta de Galicia, 1999. p. 49-74.

22. ACDF-Roma, Stanza Storica, BB 5-d. Procuração de 24 de julho de 1673.

23. ACDF-Roma, Stanza Storica, BB 5-d. Procuração de 20 de outubro de 1673. Segundo João Lúcio de Azevedo, Francisco de Azevedo era um «clérigo aventureiro», «abade prebendário em França». História dos cristãos-novos... Op. cit. p. 306. Ele foi procurador dos cristãos-novos durante quase toda a contenda.

24. A derocada de dom Afonso VI já se apresentava no horizonte quando, em 1667, demitiu seu valido, o conde de Castelo Melhor. Embora rei de direito, após o golpe de Estado arquitetado por seu irmão, dom Pedro, dom Afonso VI fora afastado e preso, não voltando mais a governar Portugal. Com a confirmação de dom Pedro como regente, os antigos aliados de dom João IV, entre eles o próprio Antônio Vieira, são reconduzidos ao centro da arena política. 
Con el rei, con el papa y con la Inquisición,

Chitón!

E senão

Irão buscar seu irmão ${ }^{25}$.

Misturavam-se ao lugar-comum ibérico as instabilidades políticas vividas em Portugal. Eram demonstrações «zelosas e atrevidas» - como chegou a qualificar as Monstruosidades - que pressionavam o regente. A conjura quase veio nesse mesmo ano, decerto facilitada por todo esse clima desfavorável ao regente, porém, foi desbaratada antes do desenlace inicial ${ }^{26}$. O núncio, monsenhor Marcello Durazzo, escreveu em 28 de setembro à Congregação romana do Santo Ofício afirmando que o príncipe havia concedido um perdão das causas passadas aos cristãos-novos e a moderação dos rigores e procedimentos da Inquisição, colocando em causa as testemunhas singulares ${ }^{27}$. A notícia (tema de mais duas correspondências) dava conta dos rumores que ameaçavam uma possível revolta dos populares, supondo que dom Pedro já havia assinado o perdão antes de partir para Caldas. Tudo não passou de boatos, mas os pasquins insistiam na pressão.

O marquês de Fronteira e outros foram «aconselhados» por um papel achado na porta do açougue (31 de julho) que não ouvissem os cristãos-novos e suas palavras «doces, enfeitadas e com diferente sentido do que são». Outras pessoas que se supunha terem votado a favor dos marranos, como o padre Quental (alcunhado de «cão e judeu»), eram injuriadas. À porta da boticária do pelourinho se juntavam muitos a falar «contra sua alteza e mais ministros», sendo que o «arcebispo de Lisboa» foi o campeão em particular ${ }^{28}$. Se o povo nas ruas ameaçava, os prelados, quase em coro, faziam suas

25. PAIX̃̃o, Frei Alexandre da, op. cit. p. 214. Vieira imaginava que se tirassem devassas de quem produzia esses pasquins, viria a tona o nome de muitos inquisidores. VIEIRA, Antônio, op. cit. Tomo II. p. 438. Carta de Antônio Vieira a Duarte Ribeiro Macedo (19 de setembro de 1671).

26. Lourenço, Maria Paula Marçal: Dom Pedro II, o pacífico (1648-1706). Lisboa: Temas \& Debates, 2010. p. $172-174$.

27. ACDF-Roma, Stanza Storica, BB 5-d. Carta do monsenhor Marcelo Durazzo à Congregação do Santo Oficio (22 de agosto de 1673). A questão era motivo de alarde não somente a Roma, os franceses também mostravam interesse e acompanhavam as notícias, como se vê na Gazette $\mathrm{n}^{\circ} 131$, de 2 de novembro de 1673. Apud Braga, Isabel Mendes Drumond \& Braga, Paulo Drumond: D. Maria Francisca Isabel de Sabóia e D. Maria Sofia Isabel de Neuburg: duas rainhas em tempo de novos equilíbrios europeus. Lisboa: Círculo de Leitores, 2011. p. 127. Para o caso do uso das «testemunhas singulares», ver: LóPEZSALAZAR, Ana Isabel: 'Che si riduca al modo di procedere di Castiglia. El debate sobre el procedimiento de inquisitorial portugués en tiempos de los Austrias’ In: Hispania Sacra, vol. LIX, n. ${ }^{119}$ (2007). FeItLER, Bruno: 'Da 'prova' como objeto de análise da práxis inquisitorial: o problema dos testemunhos singulares no Santo Ofício português. In: Ricardo Marcelo Fonseca; Airton Cerqueira Leite Seelaender (Org.). História do Direito em perspectiva: do Antigo Regime à Modernidade. Curitiba: Juruá Editora, 2008. Mattos, Yllan de. op. cit.

28. DGA/TT-Lisboa, Armário Jesuítico. Maço 29, documento 40. Papel que se achou sobre a porta do açougue em que se nomeiam e injuriam as pessoas que se supunha votarem pelos cristãos novos (31 de julho de 1673). O documento 39 desse mesmo maço também versa sobre as ameaças e injúrias: Carta do secretário de Estado, Pedro Sanches Farinha, ao confessor Manuel Fernandes, em que lhe dá notícia de 
as vozes de defesa da Inquisição portuguesa. Os mais exaltados deles eram o bispo de Leiria, dom Pedro Vieira da Silva - antigo secretário de Estado de dom João IV - e dom Luís de Souza, bispo de Lamego ${ }^{29}$.

Os inquisidores «receando que outros [pareceres discordantes] pudessem favorecer o grupo que não se opunha às pretensões dos cristãos-novos e debilitar um de seus sustentáculos», o episcopado, começaram a escrevê-los buscando seu apoio ${ }^{30}$. Ao mesmo tempo, pressionaram o regente e, por outra via, se antecipavam à sua decisão, enviando frei Luís de Beja com um crédito de 45 mil cruzados (confiscados dos cristãos-novos, segundo Vieira) para tentar dar cabo da questão em Roma. Nesse momento, alguns membros da Universidade de Coimbra também emitiram um parecer a pedido do regente no qual diziam que não se podia impedir o recurso ao papa, mas que também o Santo Ofício poderia apresentar suas razões em Roma ${ }^{31}$. Esse parecer, segundo sugeriu o confessor Manuel Fernandes, foi manipulado pelo «governador» da Universidade de Coimbra que extorquiu alguns votos a favor do recurso dos cristãos- novos $^{32}$.

Em todo caso, com a convocação das cortes, em 20 de janeiro de 1674, para a discussão da coroação de dom Pedro, do juramento da infanta e de alguns tributos a serem cobrados, o debate ganhou um novo palco. Novamente, dom Pedro Vieira da Silva foi o mais exaltado. Seu discurso inflamado defendia a Inquisição e estabelecia limites ao poder real, afirmando que os monarcas não podiam alterar foros e liberdades de seus reinos. O seu discurso, ao mesmo tempo que condenava o recurso dos cristãos-novos, colocava indiretamente em questão a possível coroação de dom Pedro: se um rei deveria observar tais condições, a licença conferida para o pleito em Roma colocava em xeque o desejo monárquico do regente. Não sem razão se exaltou o marquês de Marialva com essas e outras insinuações dos estados eclesiástico e do povo, aos berros de que «é necessário compreender que não somos o Parlamento de Inglaterra e que sua alteza é senhor soberano e absoluto deste reino e pode fazer dele o que quiser e vender-lhe se lhe parecer» ${ }^{33}$.

um pasquim, em que se prometiam graves danos às pessoas que votassem a favor do requerimento dos cristãos novos (29 de julho de 1673).

29. Sobre a participação dos prelados nesta contenda, ver: PAIVA, José Pedro: Os baluartes da fé e da disciplina: o enlace entre a Inquisição e os bispos em Portugal (1536-1750). Coimbra: Imprensa da Universidade de Coimbra, 2011. p. 240-260. Marcocci, Giuseppe; PaIVA, José Pedro, op. cit. p. 204-205.

30. PaIVA, José Pedro: Os baluartes da fé... op. cit. p. 252.

31. BA-Lisboa, 49-IV-26, n. ${ }^{\circ}$ 12. Parecer que os leitores dos Sagrados Cânones da Universidade de Coimbra deram, e aprovaram Doutores e Mestres de diversas faculdades do Colégio da mesma Universidade sobre o perdão-geral que pretenderam os cristãos-novos em Portugal e a mudança no modo de processar no Santo Oficio. (19 de fevereiro de 1674).

32. DGA/TT-Lisboa, Armário Jesuítico. Maço 29, documento 54.

33. AGS-Simancas, Secretaría de Estado-Negociación de Portugal. Legajo 2626. Carta do abade Giovanni Domenico Maserati, embaixador espanhol em Portugal, para a regente Mariana de Austria (7 de maio de 1674). Original em espanhol. Tradução nossa. Este trecho também foi citado por Ângela Barreto Xavier \& Pedro Cardim. Dom Afonso VI. Lisboa: Círculo de Leitores, 2006. p. 257. 
Os bispos estavam empenhados nessa contenda. Escreveram cartas para o papa, para a Congregação romana ${ }^{34}$ e para o cardeal Barberino, decano dessa instituição ${ }^{35}$. Ao rei, escreveram os inquisidores em 2 de maio. A carta, com «nossas lágrimas»e «sangue de Jesus Cristo», fazia vez a adular o regente, sem deixar de trazer à luz do dia as instabilidades políticas vividas, solicitando que «vossa alteza dê um ouvido para a acusação [e] dê também outro para a defensa e mostre-se tão grande como si mesmo». Segundo estes, os cristãos-novos apontaram «duas matérias em sua petição, sendo uma verdadeira e a outra industriosa: perdão-geral para as suas sacrílegas apostasias e relaxação dos estilos do Santo Ofício para viverem com liberdade, consciência, livrando-se assim dos delitos presentes e canonizando aos delinquentes passados». Nesse sentido, afirmavam que «se o procedimento do Santo Ofício é injusto, que há sido cada inquisidor senão um tirano; e que há sido cada judeu relaxado, senão um mártir». Por fim, terminam: «intento foi sempre da Inquisição de Roma, sujeitar às suas leis as Inquisições das Espanhas», impedidas pelos reis de Castela e Portugal, podendo, por isso, «embargá-la o procurador da Coroa porque em se alterarem as leis da Inquisição, prejudica-se a religião, o físco e a república» ${ }^{36}$. Esses três pontos (exaltação e advertência política; perdão e castigo; subordinação à Coroa e não a Roma) foram cerne da questão no reino. Os inquisidores chegaram a afirmar que «o residente que vossa alteza tem em Roma [...] é requerente de cristãos-novos; faz serviço do seu interesse; os seus gastos de cada ano valem mais que as duas mesadas e a sua fazenda», alegando como pretexto para enviar outro residente e outro embaixador extraordinário à Cúria ${ }^{37}$. O Estado dos Povos, por meio de seu representante Mendes Foios Pereira, também escreveu ao rei para dar mais força à questão, exclamando: «não permita vossa alteza que a Cristo preguem novamente na cruz os judeus aquele braço que despregado nos defendeu» ${ }^{38}$.

34. BNP-Lisboa, Reservados, Códice 8702. Carta que o Estado Eclesiástico junto em cortes escreveu a sagrada Congregação dos Cardeais sobre o negócio da gente da nação. Original em latim.

35. BA-Lisboa, 49-IV-26, n. ${ }^{\circ}$ 13. Carta do episcopado em Portugal para o Cardeal Barberino sobre assuntos referentes a judaismo (13 de março de 1674). PAIvA, José Pedro: Baluartes da fé e da disciplina. Op. cit. p. 254.

36. BNP-Lisboa, Reservados, Códice 8702. Carta que em nome do Tribunal do Santo Ofício se escreveu ao príncipe dom Pedro, quando regente do reino de Portugal, para que ouça e atenda ao parecer do mesmo Tribunal e dos bispos sobre o recurso da gente da nação (2 de maio de 1674).

37. Idem. Ver também: BA-Lisboa, 51-VI-21. Consulta do Conselho Geral do Santo Oficio ao príncipe dom Pedro sobre os cristãos-novos. Lisboa (30 de abril de 1674). fl. 56v.

38. BNP-Lisboa, Reservados, Códice 8702. Consulta que o Estado dos povos fez a sua Majestade sobre o perdão-geral que pretendiam os homens de nação no ano de 1674. Desse papel e da Perfídia judaica - ambos do mesmo autor -, Vieira qualificou como «cheio de tantas indignidades e meninices que me caíram as faces no chão; o estilo parecia de um novato da universidade, escrito a alguma freira tola». E pior, «isto se escreve, se lê e, porventura, se aplaude no sancta sanctorum, de onde saem os nossos oráculos!» VIeIRA, Antônio: Cartas. Op. cit. Tomo III. p. 66. Carta de Antônio Vieira a Duarte Ribeiro de Macedo (31 de julho de 1674). 
Em março, resolveram, enfim, enviar um representante a Roma - segundo os inquisidores, seria mais prudente que esse ministro não tivesse vínculo com o Tribunal. Os prelados ponderaram e Gonçalo Borges Pinto, deputado do Tribunal de Coimbra, fora nomeado seu representante, partindo em 28 de maio de 1674 para a Sé Apostólica na companhia de Jerônimo Soares - que atuaria em nome da Inquisição ${ }^{39}$. Uma instrução em 18 itens, assinada pelo bispo da Guarda, dava ao representante dos prelados seus objetivos em Roma. Portanto, os enviados de Portugal já partiram com várias incumbências, entre elas os olhos cuidadosos sobre Vieira, afinal, como afirmou dom Pedro Vieira da Silva, «tem-se por coisa muito certa que o padre Antônio Vieira, religioso da Companhia de Jesus, conhecido por sua predica, foi o motor deste negócio» ${ }^{40}$. O próprio jesuíta afirmava alcançar notícias nesse sentido: «cada dia chegam, e por muitas vias, queixas contra mim, como se eu tivera parte no que sem imaginação minha lá se propôs [o envio de recursos para Índia], lá se concedeu [licença para vir a Roma], lá se resiste [perdão-geral] e lá parece que se tornou a suspender com tanta inconstância como descrédito $\rangle^{41}$. Em outra ocasião, quando dom Pedro solicitava seus serviços em um «negócio de grandes consequências», Vieira logo pensou em se tratar «do perdão e mudança dos estilos no Tribunal do Rossio»» ${ }^{42}$.

\section{A BATALHA DE PAPÉIS E A SUSPENSÃO DO SANTO OFÍCIO}

De fato, Vieira dava conta de tudo ao padre Manuel Fernandes. Em carta escrita em 9 de setembro de 1673, o jesuíta mostrava atenção com os ocorridos em Lisboa e com as posições tomadas por cada indivíduo. Em Roma, relatava que o delegado da Inquisição, frei Luís de Beja, levara papéis («Memorial número I») para a Congregação romana a fim de que silenciassem a questão - antes mesmo que o monarca tomasse

39. Sobre a ação de Gonçalo Borges Pinto, existe o estudo de Ana Maria Homem Leal de Faria, pautando-se sobretudo em sua correspondência com os prelados, sob guarda da Biblioteca Nacional de Portugal. FAria, Ana Maria Homem Leal de: 'Uma teima...' Op. cit. José Pedro Paiva estudou uma parte da missão de Jerônimo Soares em Roma através da documentação incompleta reservada no Maço 21 do Conselho Geral do Santo Ofício, na Torre do Tombo. PAIVA, José Pedro: «Representar e negociar a favor da Inquisição: a missão de Jerônimo Soares (1674-1682)» In: GARRIDO, Álvaro; CosTA, Leonor Freire \& DuARTE, Luís Miguel: Estudos em homenagem a Joaquim Romero Magalhães: economia, instituições e império. Coimbra: Almedina, 2012.

40. BNP-Lisboa, Reservados, Códice 1532. Papel em que pede que não aceite a suplica dos cristãos novos. fl. 9-10v. Esclareceu o bispo, segundo seu arbítrio: «quem é o padre Antônio Vieira? [...] é o tal Vieira sujeito engenhoso, de juízo sutil e agudo sobremodo, como se sabe, suposto que tem tanto quanto de douto, muito presumido e não pouco teimoso». Idem.

41. VieIra, Antônio: Cartas, op. cit. Tomo II. p. 448. Carta de Antônio Vieira a Duarte Ribeiro de Macedo (7 de novembro de 1673). Sobre os rumores da participação de Vieira, há quem dissesse que estaria «preso pela Inquisição», em Roma; ou, «ainda pior», que havia «fugido de Roma com quarenta mil cruzados dos cristãos-novos». Idem. p. 458. Carta de Antônio Vieira a Duarte Ribeiro de Macedo (26 de dezembro de 1673).

42. VieIra, Antônio: Cartas, op. cit. Tomo II. p. 389. Carta de Antônio Vieira a Duarte Ribeiro de Macedo (21 de março de 1673). 
qualquer partido. Os cardeais, por sua vez, acharam melhor aguardar «os homens da nação» e não tomar «qualquer resolução que depois fosse muito dificultosa de desfazer». Vieira esperançoso assegurava «que os estilos sem dúvida serão emendados». Pelo partido dos cristãos-novos, o inaciano foi bem realista ao distinguir suas inclinações e préstimos: duvidava, na altura, da simpatia do residente pela causa, pois já não tinha suas notícias havia dias, além dos segredos que lhe ocultava. $\mathrm{O}$ advogado Tomás da Ribeira era um dos principais informantes, porém era seu desejo permanecer oculto. O abade Francisco de Azevedo - que a época ainda não era o procurador dos cristãos-novos - fora pessoa da «maior agência e valor», pois era «pratico» e possuía «amigos e entradas», além de ter «particular afeto a este negócio», devendo «em falta do residente» fazer-lhe procuração. Vieira apostava mesmo em Azevedo, pois acreditava que «fazendo a reformação dos estilos», seria necessário que se fosse a fundo em todos os pontos («que são muitos e muito miúdos») e em todas suas as cláusulas e «isto tenho por certo que o residente o não há de fazer, senão com algumas generalidades que não aproveite e fiquem mais servidos os inquisidores» de Portugal. Pedro Lupina Freire, um ex-notário da Inquisição condenado e expulso por revelar seus segredos, havia sido mandado para ajudar os cristãos-novos, «homem terrível e que pode servir ou danar muito para as notícias interiores da Inquisição», segundo sua avaliação. Era pessoa que vivia pobre, mas que por esses dias «andava luzido», podendo, então, «congraçar» com uma e outra parte ${ }^{43}$. Portanto, o contorno das cooptações que se seguiram - pelo lado dos cristãos-novos - foi, sem dúvidas, pensado e desenhado por Antônio Vieira. Mas não só. Em julho de 1674, o procurador Francisco de Azevedo escreveu suas más impressões sobre o ex-notário:

Pedro Lupina andou aqui tirando esmola para se ir e muitos caíram na ratoeira. E a três ou quatro semanas que partia de dia em dia, agora não falaria em partir. Antes dizem, espera o inquisidor, a mim não me enganou em nada porque nunca dei crédito a sua jornada, e os que criam nele, e por parvos lhe achavam, razão se desenganaram. Agora é sujeito ridículo e pouco crédito lhe darão os ministros ${ }^{44}$.

Lupina Freire não parecia gozar de muitos créditos, nem por parte dos cristãos-novos nem dos partidários da Inquisição. Jerônimo Soares havia mesmo considerado a possibilidade dele ser um espião ${ }^{45}$. De fato, parecia ser um agente duplo. Escreveu duas cartas para o Conselho Geral, em 1674 e no ano seguinte, tratando do seu processo e do por que estaria em Madri e, depois, em Roma ${ }^{46}$.

43. VieIra, Antônio: Cartas, op. cit. Tomo II. p. 428-434. Carta de Antônio Vieira ao padre Manuel Fernandes (9 de setembro de 1673).

44. DGA/TT-Lisboa, Armário Jesuitico, Caixa 30, documento 34. Carta de Francisco de Azevedo aos cristãos-novos do reino (14 de junho de 1674).

45. DGA/TT-Lisboa, Conselho Geral, Maço 21. Carta de Jerônimo Soares ao Conselho Geral do Santo Oficio (2 de novembro de 1675). fl. 251.

46. DGA/TT-Lisboa, Conselho Geral, Maço 21. Cartas de Pedro Lupina Freire ao Conselho Geral do Santo Oficio (25 de outubro de 1674; 14 de fevereiro de 1675). fls. 76; 68-69. 
Aqueles que defendiam o pleito dos cristãos-novos, contudo, corriam graves apu$\operatorname{ros}^{47}$. Azevedo logo escreveria a sua santidade solicitando imunidade para algumas pessoas tratarem dessa querela e que enquanto «a causa estivesse devoluta a Roma e indecisa» ordenasse que não houvesse relaxados nos autos da fé. Nesse rogo, afirmava, não havia qualquer inconveniente ou alteração de estilos, pois os réus continuariam presos e não seriam interrompidas novas capturas ${ }^{48}$. Mesmo o revés de ordens do regente (quando não de sua Secretaria e sem sua anuência) para o residente em Roma, primeiro apoiador, depois neutro e, por fim, contrário ao intento dos cristãos-novos, não alterou o ânimo dos reclamantes. Azevedo escrevia amiúde à Congregação e ao papa, queixando-se dos inquisidores.

Uma vez mais escreveu reafirmando que os inquisidores «davam novas provas de seu ódio contra aquelas pessoas» que de «nome comum haviam empreendido o recurso à Sede Apostólica [...] perseguindo-os com as maiores violências e com exemplo de inumanidade». O procurador afirmava que os familiares do Santo Ofício rondavam a casa de Antônio Rodrigues Mogadouro («talvez o mais rico» comerciante de Portugal), naquele momento já preso com grande parte de sua família, ameaçando os poucos membros remanescentes. Para conter esses desmandos e ameaças, o procurador solicitava uma «justa e necessária inibição» por parte dos cardeais para que os inquisidores não mais perseguissem aqueles que estavam envolvidos no recurso, alegando que era política (se não «raivosa») a prisão, pois «encarcerando as pessoas e sequestrando os bens» minaria «o crédito que entre os comerciantes é a alma do negócio» ${ }^{49}$.

Além dos próprios comerciantes cristãos-novos, a interrupção do «negócio», do comércio, era o que mais afligia Vieira. $\mathrm{O}$ inaciano fora um dos maiores defensores do comércio e, consequentemente, dos cristãos-novos - pelo mesmo motivo. Por sua vez, os inquisidores já haviam feito opinião comum sobre o assunto, ainda nos anos da União Dinástica: «tudo é interesse», «[n] que sei é que se o reino com a falta e ausência dos cristãos-novos estiver menos rico, que estará mais católico» ${ }^{50}$.

Por outro lado, tocando em uma interessante questão jurídica, o procurador alegava que

nenhuma lei permite que as partes formais sejam juízes de suas partes. Se os principais recorrentes são partes contra os inquisidores e os inquisidores são parte contra eles, inclinando o litígio à Sagrada Congregação, não podem aqueles ministros preceder como juízes direta ou indiretamente contra aquelas mesmas pessoas com as quais estão em litígio

47. DGA/TT-Lisboa, Armário Jesuítico, Caixa 30, documento 34. Carta de Francisco de Azevedo aos cristãos-novos do reino (14 de junho de 1674).

48. ACDF-Roma, Stanza Storica, BB 5-d. Carta de Francisco de Azevedo ao papa (sem data). Original em italiano, sem paginação (tradução nossa). A notícia também se encontra em: Antônio Vieira. Cartas. Op. cit. Tomo III. p. 20-21. Carta de Antônio Vieira a Duarte Ribeiro de Macedo (31 de janeiro de 1674).

49. ACDF-Roma, Stanza Storica, BB 5-d. Carta de Francisco de Azevedo a Congregação do Santo Ofício (sem data, provavelmente de maio de 1674). Original em italiano, sem paginação (tradução nossa).

50. BNP-Lisboa, Reservados, Códice 868. Parecer [de Francisco de Castro] acerca do memorial que os cristãos-novos deram ao senhor el-rei dom Filipe 3 de Portugal no ano de 1630. fl. 151. 
e fazer ato algum que os prejudique e muito menos que venha a arruinar aquelas mesmas pessoas que haviam impetrado o recurso a Sé Apostólica, vivendo sob a sua especial proteção ${ }^{51}$.

Os cristãos-novos, através de seu procurador e seus partidários tentavam a todo custo invalidar jurídica e moralmente os ministros da Inquisição, alegando incompetência de direito e «paixão» ou «raiva» no arbítrio de suas funções. Jogavam também uma ardileza: ao solicitar e se por sob a proteção papal e dos cardeais, também colocavam em xeque os inquisidores que estariam em apuros se os perseguissem. Todavia, a artimanha funcionava bem no plano do Direito, mas manquejava no cotidiano português, em que o Santo Ofício arregimentava mais e mais partidários a sua causa, agigantando-se como nunca. Os bispos e o povo eram seu sustentáculo e o regente, ainda pusilânime, era alvo de várias investidas.

Incansáveis em seu pleito, os cristãos-novos produziam uma avalanche de cartas que invadia o correio dos cardeais da Congregação, tomando a ordem de suas discussões. Quase sempre, após a leitura dessas propostas, os cardeais anotavam no verso (na última página ou na capa) seu parecer e possível resolução - quando houvesse mérito. Caso motivasse polêmica, era certo que fizessem voto ${ }^{52}$.

Mesmo entre os cardeais havia divisões políticas. Barberini trocava amiúde informações com Vieira e junto com Carpegna, Albizzi, Collona e Altieri formavam, segundo Jerônimo Soares, o partido contrário à Inquisição portuguesa e a favor dos cristãos-novos $^{53}$. De fato, alguns desses cardeais tratavam particularmente com o procurador dos cristãos-novos, trocando informações preciosas por presentes. Ao que parece, quando o papa publicou o primeiro breve suspendendo os autos da fé, Vieira e Azevedo já tinham notícia do ocorrido, ao contrário de Soares e Gonçalo Borges Pinto que sabiam tardiamente das questões. Até a chegada de dom Luís de Souza, o partido dos inquisidores estava incrivelmente desarticulado e pouco contribuía para a virada do jogo.

51. ACDF-Roma, Stanza Storica, BB 5-d. Carta de Francisco de Azevedo a Congregação do Santo Oficio (sem data, provavelmente de maio de 1674). Original em italiano, sem paginação (tradução nossa).

52. Segundo Agostino Borromeo, «a partir do pontificado de Pio V se instaurou a prática, depois mantida até o século XX, para a qual o Papa em pessoa presidia uma vez por semana as reuniões dos cardeais (geralmente às quintas-feiras, na sessão de 'feria V'). Foi, assim, afirmando o princípio segundo o qual a presidência da Congregação pertencia ao pontífice: por este motivo, a partir do século XVII e até 1965, o cardeal responsável do Santo Ofício romano não trazia nunca o título de prefetto, como ocorria em outras congregações, mas aquele de cardeal secretário. Entre o pessoal surgiu a figura do assessore, um cargo criado desde 1553. Com o tempo, o titular do encargo assume uma posição de superioridade sobre os outros ministros do Santo Ofício, sendo a ele conferida a responsabilidade de supervisionar o trabalho feito pelo restante do pessoal e a faculdade de conhecer os recursos contra as sentenças de primeiro grau nos tribunais periféricos». Esse mesmo autor afirma que entre 1670 e 1676 havia 15 cardeais na Congregação. Encontrei apenas 14 nas resoluções e as reuniões, ao menos desse caso estudado, ocorriam às «feiras 4». Borromeo, Agostino: 'Congregazione del Sant'Uffizio' In: Prosperi, Adriano (dir.): Dizionario storico dell'Inquisizione. Pisa: Edizioni della Normale, 2010. Vol. I. p. 390. Original em italiano, tradução nossa.

53. PaIVA, José Pedro: ‘Representar e negociar...', op. cit. p. 163. 
Orsini, Rospigliosi, Portocarrero e Estrées eram os cardeais com que os representantes portugueses tinham mais entradas, mostrando-se claramente seus apoiantes, sobretudo após 1676. Esses representantes do Santo Ofício português faziam de tudo para mostrar que os estilos do Tribunal eram justos e misericordiosos, não passando o pleito de um desaforo de hereges, ao ponto de o secretário da Congregação do Index avaliar, após conversa com Jerônimo Soares, que «a Inquisição portuguesa [era] mais branda que em Itália». Soares estava empenhadíssimo em trazer mais apoiantes à causa inquisitorial e, em 15 de dezembro de 1674, dava conta em carta cifrada que visitava todos os cardeais da Congregação ${ }^{54}$. Os demais eram mais neutros, embora sempre contrários à prática das testemunhas singulares - «mui odiada em Roma» -, e votariam conforme a razão que lhes cabia.

Ao que afirmava o residente Gaspar de Abreu de Freitas, os castelhanos que estavam em Roma eram os mais empenhados em dar apoio à Inquisição portuguesa, pois acreditavam «por assim o entenderem e verem que em Portugal se necessita de mais rigor do que em outras partes» ${ }^{55}$. O abade Maserati, embaixador espanhol em Portugal estava, de fato, atento a tudo, dando conta do «motim ocasionado de um breve que o núncio enviou aos inquisidores» ${ }^{56}$. A atenção do embaixador não seria pela necessidade de rigor em Portugal, mas antes, por conta de uma semelhança de estilos das Inquisições ibéricas que pudesse gerar alguma jurisprudência, alterando também o Tribunal castelhano. O residente ainda expunha ao regente sua opinião sobre o pleito, com um leve posicionamento em forma de sugestão política desinteressada ${ }^{57}$. Suas informações, na verdade, se alinhavam com o que diziam, reclamavam e pleiteavam os cristãos-novos em Portugal e Roma. Possivelmente, Gaspar de Freitas - ainda que secretamente - procurava fazer voz a este lado da batalha, ocultando sugestões em simples notícias.

Seja como for, a batalha não perdoava tréguas. O procurador resolveu atacar uma vez mais o ânimo dos inquisidores, denunciando que faziam seguidos autos da fé (com «três ou quatro meses» de diferença) para se vingarem em razão da «paixão viva e indignação concebida contra o recurso» em uma «nova carnificina e um novo massacre contra vida e contra os bens daquele povo desafortunado». Pedia, então, a suspensão das «sentenças definitivas» enquanto durasse o pleito. Porém, uma questão de pouco relevo nessa carta ganhava o ouvido dos cardeais: a condenação à justiça secular de

54. DGA/TT-Lisboa, Conselho Geral, Maço 21. Carta de Jerônimo Soares ao Conselho Geral do Santo Oficio (15 de dezembro de 1674). fl. 226.

55. Corpo diplomático português. Op. cit. Tomo XIV. p. 190. Carta do residente Gaspar de Abreu de Freitas ao príncipe regente (7 de abril de 1674).

56. AGS-Simancas, Secretaría de Estado - Negociación de Portugal. Legajo 2627. Carta do abade Giovanni Domenico Maserati, embaixador espanhol em Portugal, para a regente Mariana de Áustria (23 de dezembro de 1674). Original em espanhol. Tradução nossa.

57. Corpo diplomático português. Op. cit. Tomo XIV. p. 190. Carta do residente Gaspar de Abreu de Freitas ao príncipe regente (7 de abril de 1674). 
duas freiras de Beja, acusadas de judaizarem ${ }^{58}$. Os cardeais pediram esclarecimento ao núncio sobre a questão ${ }^{59}$. $\mathrm{O}$ fato é que o caso havia provocado péssima repercussão em Roma, pois as freiras queimadas em Évora «lhes pareciam cousa inaudita, vivendo tantos anos em clausura sempre como católicas e morrendo como tais ${ }^{60}$. As freiras relaxadas no auto da fé de 26 de novembro de 1673 foram Soror Maria da Vitória, de 49 anos, e Soror Joana das Chagas, de 55 anos $^{61}$.

«Se a conduta dos inquisidores de Portugal não desse diariamente novo motivo de admiração e escândalo, os cristãos de sangue hebreu habitantes naquele reino não seriam obrigados a importunar continuamente a Sagrada Congregação». Assim começa uma das epístolas de Francisco de Azevedo, justificando sua recorrência na «fúria» dos ministros portugueses (inquisidores e prelados) que haviam «levantado a mascara» - referindo-se as perseguições e explicitação do posicionamento quando da convocação e debate nas Cortes. Fazendo voz a uma questão de Vieira, dizia que os bispos foram todos ministros daquele Tribunal. Não faltaram críticas a Pedro Vieira da Silva e sua «vergonhosa» predicação e «doutrina mais cismática», recortando de seu discurso partes bem controversas - ora inventadas, ora produzidas pelo calor da contenda. Em uma dela, afirmava que o bispo de Leiria havia dito «que à fé católica se fazia em Roma a guerra, quando il magnum nobis Rome paratur bellum, é ditado famoso da boca de um luterano» ${ }^{62}$.

O procurador lançava a cada carta uma nova desqualificação dos partidários dos inquisidores. Esse conjunto de deméritos ia pouco a pouco construindo um senso comum sobre a prática inquisitorial de Portugal que, como é elementar, não convencia a todos, mas decerto abalava a moral de seus apoiantes. A comparação com Lutero ou a alcunha de «arbitrário» e «raivoso», posto que tendenciosa e inexata, empregava certo valor político completamente inteligível e significativo aos religiosos de Roma. A gravidade do cisma e da heresia se completa com a responsabilização do papado que, nas palavras de Azevedo, deveria ser o mais «zeloso pela conservação da justiça». Até esse momento, pouco se tocava na questão da «reforma dos estilos», ou seja, da alteração da práxis inquisitorial, e praticamente nenhuma palavra foi dita sobre «perdão-geral»embora esses temas ocupassem a pena dos apoiadores do Santo Ofício. Dissimulações, traições e meias-verdades faziam parte da contenda.

58. ACDF-Roma, Stanza Storica, BB 5-d. Carta do procurador dos cristãos-novos à Congregação do Santo Ofício (sem data, porém debatida em «feira 4, 25 de abril de 1674»). Percebe-se em outros códices do Archivio della Congregazione per la Dottrina della Fede a preocupação com a prisão e condenação de freiras pelo Santo Ofício, como em: ACDF-Roma, Stanza Storica, TT 2-1. Circa dubium an censendae sint professae moniales quae in Judaismo profissionem emittunt et an moniales catolicae quae post emissam profissionem iudaizant compelli debeant ad observantiam religionis. fl. 906-1106.

59. Idem. A informação encontra-se no verso da carta.

60. Corpo diplomático português. Op. cit. Tomo XIV. p. 193. Carta do residente Gaspar de Abreu de Freitas ao principe regente (7 de abril de 1674).

61. Os processos são, respectivamente: DGA/TT-Lisboa, Inquisição de Évora, processos n. ${ }^{\circ} 2493$ e 345.

62. ACDF-Roma, Stanza Storica, BB 5-d. Carta do procurador dos cristãos-novos à Congregação do Santo Oficio (sem data, porém debatida em 2 de maio de 1674). 
O duvidoso residente Gaspar de Abreu de Freitas mudava muito rápido suas posições políticas em razão das opções do próprio regente, sendo motivo de desconfiança para ambos os lados. Escreveu em abril que

o procurador da gente da nação, vendo que os inquisidores desse reino faziam grande repugnância ao perdão-geral [...], declarou que não queriam nenhuma graça nem indulto da Sé Apostólica, e que não pediam outra cousa mais que justiça, e que aqueles que delinquissem os queimassem, mas que não acusassem aos bons católicos; e que no processar e sentenciar se guardasse o Direito canônico e os breves pontifícios; porque eles se achavam mais acusados e tiranizados (por esta palavra) debaixo do poder da Inquisição de Portugal, do que seus antecessores no cativeiro do Egito.

Muitas razões poderiam mover a fazer esta declaração; como é dizerem que eles não querem mais que justiça, e que quem pede perdão pressupõem culpa, a qual negam; e verem que se alcançaram que os processos são mal feitos até agora, forçosamente se há de mandar que por eles se não proceda, e pelo conseguinte ficam todos os até aqui processados livres $[\ldots]^{63}$.

Sem dúvida, o abandono do discurso da misericórdia era percebido pouco a pouco nos papéis do procurador, como se pode perceber na carta em que afirma que

o ponto do perdão, tomado geralmente, foi a pedra do escândalo em que fundaram, neste reino, tantos [...] reis; e cá, nós fomos pelo contrário, sem querer falar nele diretamente, que nos deu crédito e reputação à causa, por nenhum modo pedido que seria mostrar culpa e medo ${ }^{64}$.

Vieira também expressava opinião semelhante em 3 de julho:

o que aqui pedem é que o sumo pontífice examine os estilos com que são julgados naquela Inquisição, diferente de todas as outras, [...] cessando ou remediando-se a violência que obriga a morrer ou adivinhar. Isto é o que pretende estes homens, não falando em perdão-geral, nem no demais que vulgarmente se supõe e escreve em Portugal ${ }^{65}$.

As correspondências tratam do mesmo assunto, demonstrando certa unidade de estratégias. $\mathrm{O}$ abandono dessa tópica mostrava mais que uma pretensa secularização dos objetivos dos cristãos-novos, através de seu procurador, mas uma investida jurídica, sabendo que esse tipo de discurso encontrava os ouvidos e os olhos dos cardeais e do papa. Em 30 de maio escreveu solicitando a cópia de alguns breves para mais bem fundamentar a questão, no que parece ter sido atendido. Nessa época, chegava às mãos dos cardeais um protesto escrito em nome dos prelados de 12 de março de 1674 . O bispo da Guarda provavelmente fora seu autor, seguido de diversos outros bispos do reino - como se vê em seus autógrafos. O documento, como de praxe, condenava a «perfídia judaica» e fazia um histórico dos perdões-gerais e graças concedidas, além de

63. Corpo diplomático português. Op. cit. Tomo XIV. p. 199. Carta de Gaspar de Abreu de Freitas, residente em Roma, para o regente (21 de abril de 1674). Grifo nosso.

64. DGA/TT-Lisboa, Armário Jesuítico, Caixa 30, documento 34. Carta de Francisco de Azevedo aos cristãos-novos do reino (14 de junho de 1674).

65. VieIra, Antônio: Cartas, op. cit. Tomo III. p. 59-60. Carta de Antônio Vieira a Duarte Ribeiro de Macedo (3 de julho de 1674). 
dar notícia da ação episcopal nesse negócio. O objetivo era provar que os cristãos-novos não se emendavam com perdões («o perdão-geral não será remédio para o judaísmo, antes poderá ser meio de que o continuem com maior soltura»), mas com os justos rigores da Inquisição, que devia manter a prática das «testemunhas singulares [...] mais que nas de qualquer outro [reino], [pois] era precisa a observância deste estilo» ${ }^{66}$.

Em maio, foi entregue ao papa um «arrazoado manuscrito» contra a Inquisição «de três dedos de altura de papel», copiado, traduzido e remetido à Congregação ${ }^{67}$. As queixas isoladas foram pouco a pouco ganhando volume e relevância, compondo um documento bem alentado com os agravos protestados. Na primavera de 1674, o procurador dos cristãos-novos entregou a densa edição conhecida como Gravami. O conteúdo foi debatido pelos cardeais na reunião habitual de quarta-feira (mercoledi), na qual fora criada uma comissão para analisar os papéis dos cristãos-novos, composta pelos ministros Barberino, Ottobono, Altieri, Albizzi, Carpegna, Nerli e Casanate. Esse grupo se fiaria nos relatos do núncio Marcello Durazo, arcebispo da Calcedônia, para confirmarem (ou não) as queixas e fundamentarem seus pareceres. Um dos primeiros pontos analisados fora as consequências do sacrilégio de Odivelas, entre elas a expulsão dos penitenciados e a proibição dos casamentos mistos ${ }^{68}$.

Os representantes do reino, Gonçalo Pinto e Jerônimo Soares, logo que ficaram sabendo dos Gravames, solicitaram uma cópia a fim de conhecer seus pormenores e produzirem uma resposta ${ }^{69}$. Porém, o deputado Gonçalo explicava que não lhe deram «vista dos papéis», nem o admitiram nesse «negócio como procurador dos senhores prelados», mas somente «como ministro do Santo Ofício se me participasse» ${ }^{70}$. Ao passo que o deputado ficava pouco a pouco isolado, Soares tornava-se o principal adversário da causa cristã-nova, tomando para si a tarefa de responder os diversos documentos entregues na Congregação e na Sé Apostólica.

A partir daí, uma batalha de papéis foi travada entre, de um lado, o procurador dos cristãos-novos e seus correligionários e, do outro, a Inquisição, a Coroa e os prelados lusos, sob o jugo do papado e da Congregação romana do Santo Ofício. Os Gravames foram uma espécie de memorial démodé - como aqueles produzidos na época da União Ibérica -, em que os cristãos-novos apresentaram à Sé Apostólica os motivos para se

66. ACDF-Roma, Stanza Storica, BB 5-d. Cartas dos prelados para a Congregação do Santo Ofício (12 e 13 de março de 1674). Há traduções desses requerimentos para o italiano e para o latim.

67. O adjetivo e a medida foram de crivo do residente em Roma. Corpo diplomático português. Op. cit. Tomo XIV. p. 202. Carta de Gaspar de Abreu de Freitas, residente em Roma, para o regente (5 de maio de 1674). Se a informação de Gaspar de Freitas estiver correta, os Gravames teriam sido escritos por portugueses em Roma ou em Portugal, sem qualquer interferência do procurador. Se for um papel romano - o que é mais provável - é certo que tenha contado com o auxílio de Vieira e Lupina Freire. Porém, não encontramos cópia em língua portuguesa nos arquivos do Vaticano ou de Roma.

68. ACDF-Roma, Stanza Storica, BB 5-d. Parecer dos cardeais sobre a carta do procurador dos cristãos-novos à Congregação do Santo Ofício (14 de junho de 1674). Original em latim.

69. BNP-Lisboa, Reservados, Códice 1532. Carta de Gonçalo Borges Pinto ao reino (28 de janeiro de 1676). fl. 316 .

70. Idem. fl. $316 \mathrm{v}$. 
postular a reforma dos estilos da Inquisição portuguesa. O perdão estava aquém do horizonte e não mais os apetecia. Tornavam-se, pois, a reforma jurídica e processual o ponto fulcral de seus escritos. Embora não haja menção a Vieira e Lupina Freire, é certo que tenham dado apoio decisivo à causa, tendo, provavelmente, suas sugestões e informações nessas letras. Manuel Fernandes, do reino, complementava os conhecimentos. Afinal, como poderia esse abade Francisco de Azevedo estar tão bem informado dos particulares da engrenagem da Inquisição portuguesa? Sua escolha devia-se à «entrada» que experimentava com muitas pessoas e o conhecimento de gente importante e imprescindível ao negócio, além da capacidade argumentativa de que gozava.

O documento é composto de 31 agravos, dispostos em dois livros e com muitas cópias espalhadas ${ }^{71}$. A tipologia dos temas abordados está assim distribuída: confiscações de bens; prisão sem legítima prova; longo tempo que se passa nos cárceres; impossibilidade de o réu se defender; prova do delito de judaísmo dada pela descendência de sangue cristão-novo; impossibilidade do delito de judaísmo em cristãos-velhos; prisão dos réus negativos ou diminutos sem corpo de delito comprovado; facilidade de prisão de um inocente ${ }^{72}$; distinção perniciosa entre cristãos-velhos e novos; prisão indevida; péssimas condições dos cárceres; negação dos sacramentos no cárcere, mesmo no momento da morte; impedimento do acesso aos autos dos processos, dificultado a defesa; sentenças de uma mesma forma, para libertos, relaxados, negativos, diminutos ou relapsos; excessivo rigor do Tribunal português; inexistência de benefício para a fé católica em manter o crime de judaísmo; e sobre as confissões e denunciações falsas ${ }^{73}$.

$\mathrm{O}$ documento era bem detalhado a fim de não deixar dúvidas sobre a iniquidade do procedimento da Inquisição portuguesa. Logo na primeira queixa, relatava o grau de pauperização em que ficavam os parentes daqueles que eram presos nos cárceres do Santo Ofício, alegando que ainda na fase do «sequestro de bens», quando não qualquer decisão de culpa cabal, o fisco tomava a posse de tudo transformando em «bens livres», ou seja, de fácil venda e circulação. O réu inocente, ainda que sua sentença lhe garanta a restituição dos bens sequestrados, ficava despojado de tudo por conta da dispersão deles (vendidos e alienados) e dos «altos valores» gastos pelo dilatado tempo de prisão. Para esse mal, propunha-se a nomeação de terceira pessoa para ficar responsável pelos bens sequestrados - a exemplo do que propusera dom João IV em 1652 - ou que o

71. ACDF-Roma, Stanza Storica, BB 5-d. Gravamina. Original em italiano. A cópia remetida ao papa encontra-se em: ASV [Archivio Segreto Vaticano]. Fondo Carpegna, n. ${ }^{\circ} 169$ (parte segunda) e 168 (parte primeira). Original em italiano. Há cópias dos gravames também no fundo Tribunal do Santo Ofício, da Torre do Tombo, na Biblioteca da Ajuda e na Biblioteca Nacional de Portugal.

72. ASV-Vaticano. Fondo Carpegna, n. ${ }^{\circ}$ 168. Prima parte deghi 31 Gravami espressi nel libro dato per li christiani discedenti da sangue hebreo nel regno di Portogallo com humilissime supliche alla Santita di S.S. et alla sacra Congregatione del Santo Officio. Original em italiano.

73. ASV-Vaticano. Fondo Carpegna, n. ${ }^{\circ}$ 169. Parte seconda degli 31 Gravami espressi nel libro dato per li christiani discedenti da sangue hebreo nel regno di Portogallo com humilissime supliche alla Santita di S.S. et alla sacra Congregatione del Santo Officio. Original em italiano. 
confisco só fosse praticado quando houvesse sentença final. A questão, portanto, era o sequestro e não o confisco de bens.

Nas questões que tocavam o aspecto jurídico, procurava-se denunciar que os cristãos-novos eram presos sem antes ter culpa comprovada, ficando muitos anos encarcerados (cerca de quatro, mas podendo chega a 14) até que as provas produzidas fossem suficientes para condená-lo, ou por fazer algo na prisão, ou por confessar culpas inexistentes para não ser relaxado. Alegava-se que o testemunho de cristãos-novos não tinha validade para a defesa de um réu, somente para sua acusação, na qual eram frequentemente aceitos testemunhos singulares, ou seja, discordantes do lugar, tempo e fato. A defesa era impossível, pois não se aceitavam advogados ou procuradores além daqueles do Tribunal, que não estavam lá para defender o réu, mas para «admoestar a livrar-se com confissão». A confissão, por sua vez, era muitas vezes induzida, de modo que os inquisidores sugestionavam aos presos que existiam várias provas cabais contra ele, não havendo maneira de se livrar delas senão pela confissão. Essa esperança na verdade era um engodo, mas ganhava mais força com a notícia de que um auto da fé se aproximava e tudo seria logo despachado, livrando-se se o réu daquele lugar em poucos dias.

Dizia-se que o cristão-novo «quando se livra de qualquer inocência provada nunca a experimenta, mas somente dizem [os inquisidores] que não se achou contra ele prova suficiente para pena do sambenito e confiscação e nunca se livram da ignominia de irem ao cadafalso» e abjurarem «de vehementi ou de levi, conforme julgam pela pouca prova do fisco ${ }^{74}$. Era, nesse sentido, o nome de cristão-novo que fazia dele judaizante. Mesmo que os acusados permanecessem negativos e não fosse encontrada qualquer prova material que pudesse formar corpo de delito, para o caso de algum ritual supostamente praticado, o réu era sentenciado a pena ordinária de fogo. A mesma pena era aplicada ainda para o caso de testemunhos singulares ou para réus com uma só testemunha de acusação, sendo prática totalmente contrária às leis eclesiásticas. Do mesmo modo, chama-se de «negativo», na Inquisição de Portugal, aquele réu que não denunciava parentes de primeiro grau ou que confessava suas culpas e não acusava mais ninguém ou que não confirmava ter feito algo nos cárceres que fora denunciado por algum agente do Tribunal.

Tudo isso facilitava a opressão dos inocentes, mas, conforme se dizia, era «melhor deixar sempre impunes cem réus, que correr o perigo de punir um inocente, havendo Deus deixado a si a punição daquele delito» ${ }^{75}$. Estavam feitas as denúncias que tinham por objetivo a reforma dos estilos da Inquisição portuguesa, pautando-se no discurso jurídico como fundamento de suas apelações. Essa postura se consolidava e seria, nesse momento, a força de toda argumentação dos cristãos-novos, compondo um manancial de papéis e cópias que tentavam dar cabo da ação do Santo Ofício português, propondo a observância aos estilos da Inquisição romana.

74. ASV-Vaticano. Fondo Carpegna, n. ${ }^{\circ}$ 168. Prima parte... 75. ASV-Vaticano. Fondo Carpegna, n. ${ }^{\circ}$ 169. Parte seconda... 
Os Gravames, porém, não ficariam sem resposta. O documento foi refutado ponto por ponto pelo inquisidor Jerônimo Soares, em um texto intitulado Due scritture presentate [...] dagl'inquisitori di Portugallo al serenissimo prencipe d. Pietro [...] per impedire il recorso delli christiani discendenti da sangue Hebreu alla Santa Sede Apostólica $^{76}$, mas contou com rápida resposta dos cristãos-novos, escrita sobre o nome de Riflessioni in risposta di due scritture, presentate dal Tribunale del Sancto Officio di Portogallo ${ }^{77}$, acirrando ainda mais a polêmica. O clero português investia pesado na situação, produzindo pareceres e argumentos de apoio ao Tribunal ${ }^{78}$.

$\mathrm{O}$ acesso a esses papéis, entretanto, era secreto, de modo que somente o papa e os cardeais - a quem eram endereçados - teriam entradas a ele. De que forma, portanto, representantes das partes conseguiam suas cópias a fim de produzir pronta resposta? Jerônimo Soares, por exemplo, pagava a um italiano para «ter todos os papéis dos judeus». Esse italiano desencadernava o livro que estava sobre a mesa ou na livraria de um dos cardeais da Congregação - de modo que não «faria falta a seu lugar» - e leva às noites para Soares (que não confiava em ninguém para fazer isso) que as passava copiando $^{79}$. De Francisco de Azevedo se sabe apenas que pagava a peso de ouro seus espias. Somente por meio desses métodos se fazia política em Roma, por isso ambos os lados usaram espiões e subornaram o quanto tinham dinheiro para fazê-lo.

Em junho de 1674, o procurador escreveu uma alentada carta na qual afirmava, entre outras coisas, que «os ministros vem inculcando que se coloque perpétuo silêncio sobre este negócio», persuadindo também que fora «vergonha dependerem de quatro italianos que com os estilos dos inquisidores de Roma, permaneceria coberta a heresia e sem castigo os hereges». A carta ainda explica as razões políticas da posição de dom Pedro, além de afirmar que «o nome da Inquisição é muito mais venerado» que «o nome do papa» em Portugal. Porém, «é certo» - continua - «que falando o sumo pontífice, publicando-se um breve e tratando-se da censura e excomunhão, as pessoas calariam-se ${ }^{80}$. O negócio principal - concluía - seria reparar presentemente e de qualquer forma o pernicioso o estilo do Tribunal ${ }^{81}$.

$\mathrm{O}$ efeito imediato dessas queixas fora o breve Cum dilecti filli christiani novi, promulgado em 3 de outubro de 1674 por Clemente X, decretando a suspensão dos autos da fé e dos despachos dos processos, além de avocar todos os processos a Sé Apostólica $^{82}$. Era a primeira vitória dos cristãos-novos, cujo recurso o papa tornou legítimo. A inibitória fora entregue ao núncio, que, de pronto, comunicou ao Conselho

76. ACDF, Stanza Storica, CC, 4-e. Original em italiano.

77. ACDF, Stanza Storica, CC, 4-n. Original em italiano.

78. DGA/TT, Conselho Geral do Santo Oficio, Livro 445.

79. DGA/TT-Lisboa, Conselho Geral, Maço 21. Carta de Jerônimo Soares ao Conselho Geral do Santo Oficio (15 de dezembro de 1674). fl. 149-155.

80. A expressão italiana mettere la bocca in terra significa calar ou silenciar um adversário.

81. ACDF-Roma, Stanza Storica, BB 5-d. Carta do procurador dos cristãos-novos à Congregação do Santo Ofício (sem data, porém debatida em 14 de junho de 1674). Original em italiano, tradução nossa.

82. Corpo diplomático português. Op. cit. Tomo XIV. p. 221-224. Original em latim. 
Geral, com a finalidade de a ordem ser replicada aos tribunais de distrito - sob o risco das penas previstas na bula da santa cruzada ${ }^{83}$. O Conselho respondeu ao núncio com a informação de que o Tribunal de Coimbra havia marcado um auto da fé para 11 de novembro e que, caso qualquer cancelamento se praticasse, temia-se pela vida dos réus, pois a população revoltada poderia queimar todos vivos nos cárceres ${ }^{84}$. Embora tal argumentação fosse um tanto exagerada, não convinha colocar a prova sobre a inaudita intolerância portuguesa. O núncio recuou e permitiu que o auto se realizasse sem relaxados, o que ocorreu na Praça de São Miguel no domingo de 18 de novembro, com 142 penitenciados (nenhum deles relaxados ou com penas de confisco) ${ }^{\mathbf{8 5}}$. Possivelmente, a inibitória ainda teria provocado a ira de dom Pedro, pois a intervenção papal feria sua regalia e autoridade. Foi nesse momento que o regente se decidiu pelo partido dos inquisidores.

Mesmo com a primeira vitória expressiva, os cristãos-novos não relaxavam em combate. Em carta de novembro de 1674, o procurador dos cristãos-novos buscou contestar o modo como se promoviam deputados e inquisidores aos tribunais e ao Conselho Geral de Portugal. O papel colocava em relevo a suposta inabilidade do inquisidor geral (ou por vezes o próprio Conselho Geral, no período de vacância) para eleger homens aos postos inquisitoriais sem precisar de qualquer aprovação de Roma. Toda a argumentação - explica-se no documento -, «para o remédio de tantos» que passam pela «horrível injustiça e violência», imploram a «justiça e a misericórdia da Sé Apostólica» e dos cardeais para que torne «nulo e de nenhum valor todos os atos e processos feitos por estes senhores ${ }^{86}$. Sobre o provimento dos cargos inquisitoriais, Vieira não se conformava. Ao longo de suas cartas, correntemente utilizava o péssimo exemplo - segundo seu juízo, claro - de Francisco de Castro e Sebastião César de Menezes para afirmar que na Inquisição se encastelavam muitos traidores. Porém, a preocupação do jesuíta era a oposição política que alguns inquisidores faziam à saúde da monarquia, chegando a afirmar que

aqui [em Roma] se diz publicamente que em Portugal é melhor ser inquisidor que rei; e eu não sei que modo de reinar é ter ministros que encontrem publicamente as minhas resoluções e tão poderosos que ou per si ou por outros, ou outros com as costas neles, façam rosto a quem só deverá ser poderoso. Por que não faz o príncipe um tal inquisidor

83. ASV-Vaticano, Segretaria di Stato - Portogallo, Segnatura 29. Carta do núncio Marcello Durazo a Sé Apostólica (10 de novembro de 1674). fl. 448-449v. Original em italiano.

84. ASV-Vaticano, Segretaria di Stato - Portogallo, Segnatura 29. Cópia da Carta do Conselho Geral ao núncio Marcello Durazo (8 de novembro de 1674). fl. 444. Original em italiano. A informação sobre queimar vivo os presos está em PAIxÃo, frei Alexandre da: Monstruosidades..., op. cit. p. 286.

85. Conforme Moreira, Antônio Joaquim \& MendonçA, José Lourenço de: «Autos de fé celebrados em Portugal e Goa» In: História dos principais atos e procedimentos da Inquisição em Portugal. Lisboa: Círculo de Leitores, 1980. Segundo o relato das Monstruosidades, houve doze relaxados em estátua neste auto. PAIXão, frei Alexandre da, op. cit. p. 286.

86. ACDF-Roma, Stanza Storica, BB 5-d. Carta do procurador dos cristãos-novos à Congregação do Santo Oficio (sem data). fl. 217-230v. Original em italiano, tradução nossa. 
que seja seu, e que sejam seus os que ele fizer, e com isso não seja necessário nem recorrer nem infamar em Roma? ${ }^{87}$

Seja como for, também no reino foram produzidos papéis que, como sempre, eram atribuídos a Antônio Vieira. O Memorial a favor da gente da nação hebreia sobre o recurso que intentava ter em $\operatorname{Roma}^{88}$, de 1674 , fora escrito após a mudança de posição adotada pelo regente ${ }^{89}$ e com o objetivo de tentar convencê-lo de que os inquisidores agiam com ódio. Afinal, «se no juiz há ódio, por mais justificada que seja a inocência do réu, nunca a sentença do juiz há de ser justa ${ }^{90}$. Os argumentos utilizados eram: a) que Jesus havia escolhido «para se aparentar com a natureza humana, nenhum outro sangue [...] senão desta gente», do qual também eram muitos santos e papas; b) que dizer que todos os cristãos-novos eram maus seria «erro patente e efeito do ódio com que é vista esta causa»; c) que se sabia mais das práticas judaicas pelos autos da fé que pelo escândalo de serem públicas, pois das quais não havia qualquer notícia; d) que quando os presos se libertam com inocência, «ficam com a nódoa que causam aquelas prisões na honra, com achaques que causam na saúde, com dispêndios que causam na fazenda»; e) que sobre os negativos, «não fica pessoa a quem saibam o nome que não acuses», e que, sobre os diminutos, «de cem, não há um que não morra inocente»; f) que estranhamente o judaísmo, conforme fazem os inquisidores, «com o castigo anda em viveiro perpétuo».

\section{CONCLUSÃO}

Embora todas as inquisições tenham sofrido críticas aos seus procedimentos, à sua jurisdição e à sua existência, a instituição portuguesa lutou em diversas frentes. No episódio que levou o pleito dos cristãos-novos a Roma, na década de 1670, o clero secular foi partidário da Inquisição enquanto os jesuítas (sobretudo Vieira e Fernandes) se configuravam como os maiores adversários do século XVII - garantindo o intento. As diversas críticas e os memoriais foram se aprimorando conforme o passar do tempo a partir da uma resistência formada/tomada na experiência de luta. Em todo o seiscentos (e, sobretudo, no pedido de perdão-geral de 1674), utilizaram-se estratégias semelhantes, porém, com resultados bem diferentes. Nota-se, em seus memoriais e opúsculos, a mudança do discurso utilizado: deixa-se a misericórdia para adotar uma

87. VieIRA, Antônio: Cartas, op. cit. Tomo II. p. 434. Carta de Antônio Vieira a Duarte Ribeiro de Macedo (26 de setembro de 1673).

88. VIEIRA, Antônio: «Memorial a favor da gente da nação hebreia sobre o recurso que intentava ter em Roma, exposto ao sereníssimo senhor príncipe dom Pedro, regente deste reino de Portugal» In: Em defesa dos judeus. Lisboa: Contexto, 2001. p. 129-149.

89. Inclusive, diante do parecer de dom Pedro que desfazia suas ordens iniciais, Vieira chegou a afirmar que «enquanto sua alteza tem semelhantes intérpretes de suas resoluções faz bem em não se coroar». VIEIRA, Antônio: Cartas, op. cit. Tomo III. p. 73. Carta de Antônio Vieira a Duarte Ribeiro de Macedo (28 de agosto de 1674).

90. Idem. p. 130. 
postura mais ligada à política e ao direito. Os escritos ganhavam, assim, uma linguagem fundamentada juridicamente, no qual condenavam os estilos do Tribunal, sobretudo o segredo no processo, a infâmia e o uso de testemunhas singulares ou mesmo falsas. Politicamente, declaravam que os inquisidores eram completamente parciais ao julgarem os cristãos-novos, imputando a injustiça desta «mácula de sangue». Os homens da nação foram incansáveis nesta luta e causaram muita dor de cabeça aos inquisidores. Eles resistiram e criaram sua estratégia para - nesta ordem - amenizar, desqualificar e dilapidar o Tribunal. Foram perseguidos e injustiçados, mas também fizeram valer suas críticas, seja no reino ou em Roma. 